\section{Aims and Scope}

The Fournal of Radiotherapy in Practice is a peerreviewed journal covering all of the current modalities specific to clinical oncology and radiotherapy. The Journal aims to publish quality research from a wide range of styles and encourage debate and the exchange of information and opinion from within the field of radiotherapy practice and clinical oncology. The Journal also aims to encourage technical evaluations and case studies as well as equipment reviews that will be of interest to an international radiotherapy market.

The Fournal of Radiotherapy in Practice aims to provide an easily available forum for education matters by publishing regular high-standard Continuing Professional Development articles.

\section{Publisher}

Dan Edwards, Commissioning Editor, Cambridge University Press, Journals, University Printing House, Shaftesbury Road, Cambridge CB2 8BS, UK.

Tel: 44 (0)1223 326491

Fax: 44 (0)1223 325802

E-mail: dedwards@cambridge.org

\section{Subscriptions}

Fournal of Radiotherapy in Practice is published annually in one Volume of four Issues in March, June, September and December. The subscription rate for 2012, Volume 11 is:

- Individual rate $f^{115}$ or $\$ 220$

- Institutional rate $£ 265$ or $\$ 495$

Correspondence concerning subscriptions should be addressed to: Journals Customer Services, Cambridge University Press, Edinburgh Building, Cambridge CB2 8RU, UK.

Tel: +44 (0)1223 326070

Fax: +44 (0)1223 325150

E-mail: journals_subscriptions@cambridge.org

Web: www.cambridge.org; Cambridge Journals

Online: www.journals.cambridge.org.

\section{Advertising Sales}

Please contact Cambridge University Press, Advertising and Special Sales, Journals, University Printing House, Shaftesbury Road, Cambridge

CB2 8BS, UK.

Tel: +44 (0)1223 325757

Fax: +44 (0)1223 325802

E-mail: ad_sales@cambridge.org
The Fournal of Radiotherapy in Practice will include research papers, scientific papers, technical articles, case studies and review articles relevant to anyone with an interest in clinical oncology and radiotherapy including: research; treatment planning; radiotherapy techniques/ protocols; portal imaging; continuing professional development; education and training; new technology; networking.

The Editor-in-Chief welcomes any suggestions to submission of manuscripts to the journal. Please refer to the online Instructions to Authors available at www.journals.cambridge.org/jrp. Please write to the Editor-in-Chief if you require further assistance in submitting an article for publication.

\section{Abstracting/Indexing}

The Fournal of Radiotherapy in Practice is indexed and abstracted in EMBASE/Excerpta Medica.

\section{Copyright}

ISSN 1460-3969

(C) Cambridge University Press 2012. Apart from fair dealing for the purposes of research or private study, or criticism or reviews, as permitted under the Copyright, Designs and Patents Act, 1988, this publication may only be reproduced, stored or transmitted, in any form or by any means, with the prior permission in writing of the publishers (Cambridge University Press, Edinburgh Building, Shaftesbury Road, Cambridge, CB2 8RU, UK), or in the case of reprographic reproduction in accordance with the terms of licences issued by the Copyright Licensing Agency, 90 Tottenham Court Road, London WIP 9HE, UK.

Notes to users in USA. Authorisation to photocopy items for internal or personal use is granted by Cambridge University Press provided that the appropriate fees are paid directly to the Copyright Clearance Center, 222 Rosewood Drive, Danvers, MA 01923, USA. For more information please contact CCC. For territories outside North America, permission should be sought direct from the copyright holder. This consent does not extend to other kinds of copying, such as copying for general distribution, for advertising and promotional purposes, for creating new collective works, or for resale.

Typeset by NewGen Imaging Systems Private Limited, Chennai, India. Printed in Great Britain by Bell \& Bain.

This journal issue has been printed on FSC-certified paper and cover board. FSC is an independent, non-governmental, not-for-profit organization established to promote the responsible management of the world's forests. Please see www.fsc.org for information. 
JOURNAL OF

\title{
RADIOTHERAPY IN PRACTICE
}

\section{CONTENTS}

Editorial

In this issue

GUEST EDITORIAL

Airport whole body X-ray scanners

Syed F. Akber

ORIGINAL ARTICLES

The introduction of lung stereotactic body radiotherapy in the UK. . . it's now a reality!

A Needham, D Hutton, A Baker

Long-term experience with 181 patients who received transperineal I-125 implants for prostate cancer:

Efficacy and urinary toxicity

Eliahu Gez, Joshua Genesin, Daniel Shahar, Valeriya Semenisty, Tanya Mashiac, Rachel Bar Deroma, David Kakiashvili,

Abraham Kuten, Simon Meretyck

Shape of things to come: factors affecting an ethnographic study in radiation therapy

Susan Merchant, Georgia Halkett, Moira O'Connor

LITERATURE REVIEWS

The prevalence, detection and intervention for depression and anxiety in oncology

David Andrew Boothroyd, Denyse Hodgson

Management of erythema and skin preservation; advice for patients receiving radical radiotherapy to the breast: a systematic literature review

K. Butcher, K. Williamson

In vivo dosimetry; essential or unnecessary?

Jenna L Leman

CASE STUDY

Breast conservation surgery and radiation for a patient with synchronous primary breast cancers and BRCA1/BRCA2 positivity: is mastectomy required?

Mark Trombetta, Katherine Kotinsley, Thomas B. Julian

Commentary

\section{Sign up to Cambridge Journals Online}

\author{
You can now: \\ > Access complimentary sample material \\ > Register for table-of-contents email alerts and stay up-to-date with the latest findings \\ $>$ Save searches \\ > Download citations to reference management software
}

To register, visit journals.cambridge.org/register

Cambridge Journals Online

For further information about this journal

please go to the journal website at:

http://www.journals.cambridge.org/jrp
CAMBRIDGE UNIVERSITY PRESS 